\title{
Ricinoleic Acid Stimulation of Active Anion Secretion in Colonic Mucosa of the Rat
}

\author{
Lorraine C. Racusen and Henry J. Binder, Department of Internal Medicine, \\ Yale University, New Haven, Connecticut 06510
}

A B S T RA C T Perfusion of the colon with ricinoleic acid produces fluid and electrolyte accumulation. The mechanism of these changes in water and electrolyte movement is unknown. These studies were designed to determine whether ricinoleic acid affects active ion transport across isolated rat colonic mucosa. $0.5 \mathrm{mM} \mathrm{Na}$ ricinoleate produced significant increases in potential difference $(3.8 \pm 0.5 \mathrm{mV})$ and short-circuit current ( $\left.I_{\text {sc }}\right)\left(99.2 \pm 10.1 \mu \mathrm{A} / \mathrm{cm}^{2}\right)$. The increases in $\mathrm{I}_{\mathrm{sc}}$ produced by $\mathrm{Na}$ ricinoleate were inhibited by both removal of bicarbonate and chloride and by the presence of theophylline. The hydroxy fatty acid also resulted in a significant decrease in net $\mathrm{Na}$ absorption from $4.7 \pm 0.8$ to $0.1 \pm 0.7 \mu \mathrm{eq} / \mathrm{h} \mathrm{cm}{ }^{2}$ and reversed net $\mathrm{Cl}$ transport from absorption $(+4.5 \pm 0.9)$ to secretion $\left(-2.2 \pm 0.8 \mu \mathrm{eq} / \mathrm{h} \mathrm{cm}^{2}\right)$. In parallel studies $0.5 \mathrm{mM} \mathrm{Na}$ ricinoleate increased mucosal cyclic AMP content by $58 \%$. The concentrations of $\mathrm{Na}$ ricinoleate required to produce detectable and maximal increases in both $I_{\text {sc }}$ and cyclic AMP were the same. These results provide evidence in support of the concept that hydroxy fatty acid-induced fluid and electrolyte accumulation is driven by an active ion secretory process.

\section{INTRODUCTION}

Perfusion of the small or large intestine with hydroxy fatty acids results in fluid and electrolyte accumulation $(1-5) \cdot{ }^{1}$ The cathartic effect of castor oil and the diarrhea that frequently accompany steatorrhea represent the clinical manifestation of this phenomenon. The mechanism by which hydroxy fatty acids produce

Dr. Racusen was the recipient of a National Research Service Award (AM 05389) from the National Institute of Arthritis, Metabolism, and Digestive Disease.

Received for publication 24 April 1978 and in revised form 15 December 1978.

"The term fluid and electrolyte "accumulation" rather than "secretion" is used to describe the addition of water and electrolytes to a solution perfusing a segment of intestine. The term secretion is restricted to designate active transport processes (e.g., that which is stimulated by cholera enterotoxin). fluid and electrolyte accumulation is unknown. Recent studies of the mechanism of other diarrheal conditions have emphasized the importance of active ion secretory processes as the driving force for fluid accumulation. For example, cholera enterotoxin, vasoactive intestinal polypeptide, and prostaglandins stimulate active ion secretion in the small and large intestine $(6-10)$.

Although there are several studies that demonstrate that ricinoleic acid either decreases net fluid and electrolyte movement or stimulates net fluid and electrolyte accumulation $(1-5,11-18)$, there is no existing evidence that ricinoleic acid stimulates active ion secretion. These previous studies have been either in vivo experiments $(1-5)$ or in vitro ones $(11-13)$ in which the electrical potential difference $(P D)^{2}$ had not been controlled and were not designed to establish the presence of active ion secretion. In addition, hydroxy fatty acids have other effects on intestinal function, such as increasing mucosal permeability, decreasing the electrical PD, altering motor activity, and producing morphological changes in the intestinal mucosa $(4,5,14-18)$. Several recent reports have emphasized the possible importance of increased mucosal permeability in the production of hydroxy fatty acid-induced fluid accumulation $(4,5,13)$. Although an increase in mucosal permeability may contribute to fluid and electrolyte secretion under in vivo conditions, such changes should not affect net ion movement across short-circuited intestinal mucosa. This study was specifically designed to determine the effect of ricinoleic acid, a hydroxy fatty acid, on colonic ion transport in vitro under short-circuited conditions. In addition, because several other active ion secretory processes are believed mediated by cyclic AMP (6-10), the effect of ricinoleic acid on mucosal cyclic AMP was also assessed.

${ }^{2}$ Abbreviations used in this paper: $\mathrm{I}_{\mathrm{sc}}$, short-circuit current; $J_{\mathrm{ms}}$, mucosal to serosal flux; $\mathrm{J}_{\text {net }}$, net flux; $\mathrm{J}_{\mathrm{sm}}$, serosal to mucosal flux; PD, electrical potential difference. 


\section{METHODS}

Nonfasting male Sprague-Dawley rats weighing between 250 and $300 \mathrm{~g}$ were used in all experiments. After sacrifice, the colon was isolated and rinsed with cold saline. The serosal and part of the muscular layers of the colon were stripped and the mucosa was mounted in a modified Ussing chamber as described (19). Because sodium ricinoleate precipitates in the presence of at least $0.5 \mathrm{mM}$ calcium, a noncalcium-containing bathing solution was required. Preliminary studies demonstrated that tissue integrity as manifested by the electrical resistance of the mucosa, was not maintained in the absence of calcium in the mucosal solution. We observed however, that when strontium was substituted for calcium, the electrical parameters of the colonic mucosa were maintained as well as, or better than, in the presence of calcium and that ricinoleic acid did not precipitate. The composition of incubation media was in millimoles per liter: $\mathrm{Na}, 140 ; \mathrm{K}, 5.2 ; \mathrm{Sr}, 1.2 ; \mathrm{Mg}, 1.2 ; \mathrm{Cl}$, 119.8; $\mathrm{HCO}_{3}, 25$; and $\mathrm{HPO}_{4}, 4.8 ; \mathrm{pH}, 7.4$. In certain experiments, a bicarbonate-free, low chloride, strontium-containing solution (referred to as $\mathrm{HCO}_{3}$-free, Cl-free solution) was employed; isethionate was used to replace chloride and bicarbonate in these studies. The only chloride present was $1.2 \mathrm{mM}$ chloride in the form of strontium chloride.

The spontaneous transmembrane electrical PD and short-circuit current $\left(\mathrm{I}_{\mathrm{sc}}\right)$ were measured as described $(19,20)$. After the $P D$ and $I_{\text {sc }}$ had stabilized, $0.5 \mathrm{mM}$ sodium ricinoleate was added to the mucosal solution of experimental tissues only. Changes in PD and $I_{s c}$ were determined by comparing the peak $P D$ and $I_{s c}$ in the $10-m i n$ period after the addition of the hydroxy fatty acid with the $P D$ and $I_{s c}$ present immediately before its addition. Uni- directional $\mathrm{Na}$ fluxes were determined across the same piece of tissue with ${ }^{22} \mathrm{Na}$ and ${ }^{24} \mathrm{Na}$; oppositely directed $\mathrm{Cl}$ fluxes were determined in paired tissues from the same animal with ${ }^{36} \mathrm{Cl}$. In these experiments, control flux measurements were made during two 20 -min periods in both experimental and control tissues. $0.5 \mathrm{mM}$ sodium ricinoleate was then added to the mucosal solution. Studies were done to determine the appropriate time to perform $\mathrm{Na}$ and $\mathrm{Cl}$ fluxes after the addition of $\mathrm{Na}$ ricinoleate (Fig. 1). In these experiments, the rate of both $\mathrm{Na}$ and $\mathrm{Cl}$ entry into the "unlabeled reservoir" was determined at 5.0-min intervals before and 2.5-min intervals after the addition of the hydroxy fatty acid. During the initial 5 min after the addition of $\mathrm{Na}$ ricinoleate there was a rapid increase and decrease of $I_{s c}$ and $P D$, an increase in conductance, and a change in the rate of all four unidirectional fluxes. However, during the period from 7 to 22 min after the addition of the hydroxy fatty acid, both the conductance and all unidirectional fluxes were stable. Therefore, a single 15 min flux determination was obtained starting $7 \mathrm{~min}$ after the addition of hydroxy fatty acid. In other studies, $0.5 \mathrm{mM}$ sodium ricinoleate was added to tissue $20 \mathrm{~min}$ after the addition of theophylline or $10 \mathrm{mM}$ theophylline was added after the addition of ricinoleic acid.

Assays of cyclic AMP levels were performed with pieces of tissue weighing between 25 and $50 \mathrm{mg}$ from stripped colonic mucosa. These tissues were incubated with continuous oxygenation in the absence and presence of several concentrations of sodium ricinoleate for varying periods of time. At the end of the incubation period, the tissue was homogenized in an ether-alcohol solution as described (21). Cyclic AMP was measured according to the method of Brown et al. (22); protein by the method of Lowry et al. (23).
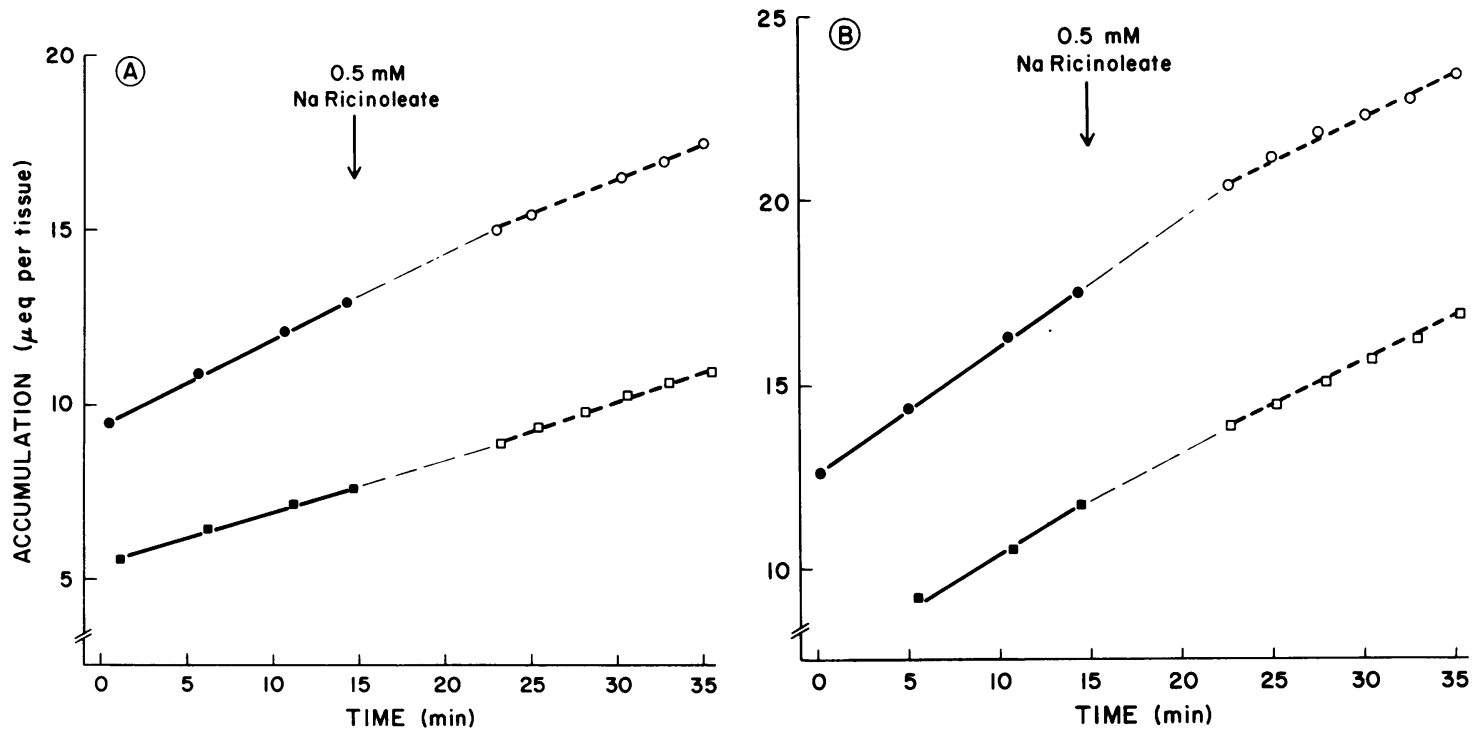

FIGURE 1 Demonstration of $\mathrm{Na}$ and $\mathrm{Cl}$ fluxes at steady-state conditions before and after the addition of ricinoleic acid. Sodium fluxes are presented in the left panel (A) and chloride fluxes in the right panel (B). The $0.5-\mathrm{mM}$ ricinoleic acid was added to the mucosal bathing solution at the arrow; samples obtained before its addition are depicted by solid figures connected by a solid line, and those obtained after its addition by open figures connected by a broken line. $J_{\mathrm{ms}}$ is represented by circles and $\mathrm{J}_{\mathrm{sm}}$ by squares. Samples were obtained every $5 \mathrm{~min}$ before the addition of the hydroxy fatty acid and every $2.5 \mathrm{~min}$ after. Reestablishment of a constant rate of movement of $\mathrm{Na}$ and $\mathrm{Cl}$ across the colonic mucosa was demonstrated by 7.5 min after the addition of ricinoleic acid. In subsequent flux studies a 15-min postricinoleic acid period (Table III) was obtained starting at $7.5 \mathrm{~min}$. 
Cyclic AMP content was expressed as picomoles per milligram protein.

Materials. Sodium ricinoleate and theophylline were obtained from K \& K Laboratories, Inc. (Plainview, N. Y.); ${ }^{22} \mathrm{Na},{ }^{24} \mathrm{Na}$, and ${ }^{36} \mathrm{Cl}$ from $\mathrm{New}$ England Nuclear (Boston, Mass.).

Statistics. Paired and unpaired Student's $t$ test were employed as indicated (24).

\section{RESULTS}

The addition of $0.5 \mathrm{mM}$ sodium ricinoleate to the Ringer (strontium containing) solution resulted in a prompt increase in both $I_{s c}$ and PD (Fig. 2). The mean peak increase in $\mathrm{PD}$ was $3.8 \pm 0.5 \mathrm{mV}$ and the peak increase in $\mathrm{I}_{\text {sc }}$ was $99.2 \pm 10.1 \mu \mathrm{A} / \mathrm{cm}^{2}$. Dose-response studies indicate that the threshold for the increase in $\mathrm{I}_{\mathrm{sc}}$ was between 0.01 and $0.1 \mathrm{mM}$ (Table I).

The addition of theophylline to rat colonic mucosa has also been shown to result in a prompt increase in $I_{s c}$ and PD (19); this increase is not observed when bicarbonate and chloride are omitted from the bathing solution (Table II). When sodium ricinoleate was added to tissue bathed in bicarbonate-free, chloridefree solution, the increases in $I_{s c}$ and $P D$ were markedly impaired (Table II). Under these conditions, the peak increase in $I_{\text {sc }}$ was $14.0 \pm 3.9 \mu \mathrm{A} /$ $\mathrm{cm}^{2}(P<0.001)$ and the increase in PD was $0.6 \pm 0.2$ $\mathrm{mV}(P<0.001)$. When $10 \mathrm{mM}$ theophylline was added to tissues after the addition of $0.5 \mathrm{mM}$ sodium ricinoleate, the increase in $I_{s c}$ and $P D$ in response to the phosphodiesterase inhibitor was markedly reduced. Further, when sodium ricinoleate was added to tissue previously exposed to $10 \mathrm{mM}$ theophylline, a significant increase in $I_{\text {sc }}$ or $P D$ did not occur (Table II).

Table III presents the results of unidirectional and net $\mathrm{Na}$ and $\mathrm{Cl}$ fluxes across colonic mucosa.

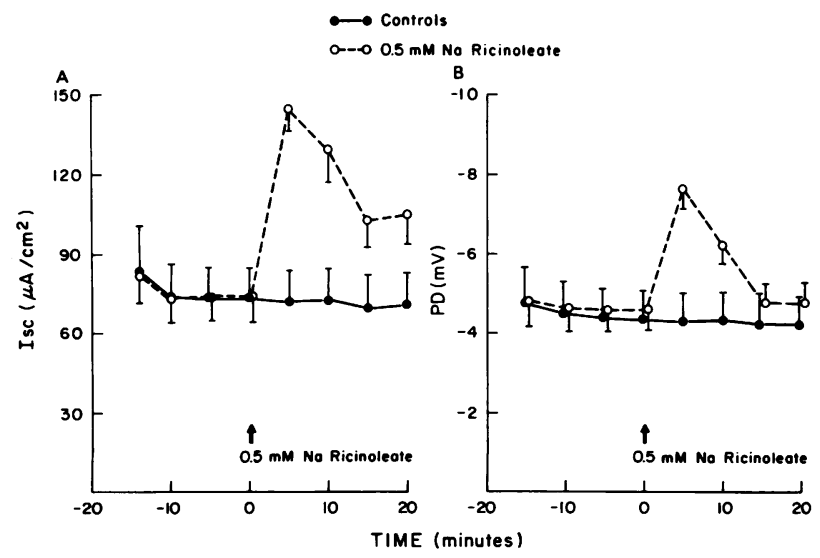

Figure 2 Effect of $0.5 \mathrm{mM} \mathrm{Na}$ ricinoleate on $\mathrm{I}_{\text {sc }}$ (A) and PD (B). The hydroxy fatty acid added to the mucosal surface of tissues bathed in a calcium-free, strontium-containing Ringer solution resulted in a prompt increase in both $I_{s c}$ and $P D$.
TABLE I

Effect of Sodium Ricinoleate on Mucosal Cyclic AMP Content and $I_{s c}$

\begin{tabular}{ccc}
\hline Na ricinoleate concentration & Increase in $\mathrm{I}_{\mathrm{sc}}$ & Mucosal cyclic AMP \\
\hline$m M$ & $\mu A / \mathrm{cm}^{2 *}$ & pmollmg protein \\
0 & $0.5 \pm 3.3$ & $10.1 \pm 0.8$ \\
0.01 & $0.3 \pm 5.4$ & $10.4 \pm 1.0$ \\
0.1 & $24.9 \pm 5.9^{\prime \prime}$ & $12.8 \pm 1.0 \$$ \\
0.5 & $62.7 \pm 7.6^{\|}$ & $16.0 \pm 1.3$ \\
1.0 & $40.5 \pm 13.1^{11}$ & $13.0 \pm 1.1 \S$ \\
2.0 & $31.6 \pm 4.7$ & $10.7 \pm 0.9$
\end{tabular}

* Results (mean $\pm S E M$ ) represent the peak increase in $I_{s c}$ noted during the $10 \mathrm{~min}$ after the addition of sodium ricinoleate compared to that observed immediately before addition. A minimum of six tissues were used at each concentration.

$\$$ The results represent mean \pm SEM of four experiments and each experiment was performed in triplicate. Mucosa was incubated in vitro with varying concentrations of $\mathrm{Na}$ ricinoleate for $10 \mathrm{~min}$. Method for cyclic AMP determination is described in the text and has been published (21).

$\$ P<0.05$ compared to control.

" $P<0.01$ compared to control.

I $P<0.001$ compared to control.

During period I, before the addition of sodium ricinoleate, there was net $\mathrm{Na}$ absorption in both the control and experimental tissues $(5.7 \pm 0.6$ and 4.0 $\pm 0.6 \mu \mathrm{eq} / \mathrm{h} \cdot \mathrm{cm}^{2}$ ). The addition of $0.5 \mathrm{mM}$ sodium ricinoleate to experimental tissues resulted in a marked decrease in net $\mathrm{Na}$ absorption $\left(\mathrm{J}_{\text {net }}^{\mathrm{Na}}\right)(0.1 \pm 0.7$ $\left.\mu \mathrm{eq} / \mathrm{h} \cdot \mathrm{cm}^{2}, P<0.02\right)$. Active $\mathrm{Cl}$ absorption was also present in the both groups during period I $(4.8 \pm 1.7$ and $\left.3.6 \pm 1.6 \mu \mathrm{eq} / \mathrm{h} \cdot \mathrm{cm}^{2}\right)$. Net Cl secretion $(-2.2 \pm 0.8$ $\mu \mathrm{eq} / \mathrm{h} \cdot \mathrm{cm}^{2}$ ) was seen in sodium ricinoleate-treated tissues, whereas $\mathrm{Cl}$ absorption in control tissues remained unchanged during period II. Thus, the presence of the hydroxy fatty acid was associated with the reduction in $\mathrm{J}_{\mathrm{net}}^{\mathrm{Na}}$ to zero and a reversal of $\mathrm{Cl}$ transport from net absorption to net secretion.

The predominant change in the unidirectional fluxes of both $\mathrm{Na}$ and $\mathrm{Cl}$ in the presence of sodium ricinoleate was a decrease in mucosal to serosal flux $\left(\mathrm{J}_{\mathrm{ms}}\right)$. $\mathrm{J}_{\mathrm{ms}}^{\mathrm{Na}}$ and $\mathrm{J}_{\mathrm{ms}}^{\mathrm{Cl}}$ decreased by 2.7 and $6.3 \mu \mathrm{eq} / \mathrm{h} \cdot \mathrm{cm}^{2}$ respectively after the addition of the hydroxy fatty acid. No significant change occurred in the serosal to mucosal fluxes $\left(\mathrm{J}_{\mathrm{sm}}\right)$ of either $\mathrm{Na}$ or $\mathrm{Cl}$. These changes in $\mathrm{Na}$ and $\mathrm{Cl}$ transport were associated with a significant increase in $I_{s c}\left(1.2 \mu \mathrm{eq} / \mathrm{h} \cdot \mathrm{cm}^{2}\right)$. Residual flux that probably represents bicarbonate secretion, rose $0.5 \mu \mathrm{eq} / \mathrm{h} \cdot \mathrm{cm}^{2}$ in controls from period I-II and fell $0.7 \mu \mathrm{eq} / \mathrm{h} \cdot \mathrm{cm}^{2}$ in $\mathrm{Na}$ ricinoleate-treated tissue, but these changes were not significant. The addition of sodium ricinoleate in these studies resulted in a significant increase in conductance. 
TABLE II

Effect of $0.5 \mathrm{mM}$ Sodium Ricinoleate and $10 \mathrm{mM}$ Theophylline on $I_{s c}$ and PD Across Isolated Colonic Mucosa*

\begin{tabular}{|c|c|c|c|c|c|c|}
\hline \multirow[b]{2}{*}{ Condition } & \multicolumn{3}{|c|}{$\begin{array}{l}\text { Addition of sodium ricinoleate } \\
\text { increase in }\end{array}$} & \multicolumn{3}{|c|}{$\begin{array}{l}\text { Addition of theophylline } \\
\text { increase in }\end{array}$} \\
\hline & & $I_{s c}$ & PD & & $I_{s c}$ & PD \\
\hline & $n$ & $\mu \mathrm{A} / \mathrm{cm}^{2}$ & $m V$ & $n$ & $\mu \mathrm{A} / \mathrm{cm}^{2}$ & $m V$ \\
\hline Ringer solution & 30 & $99.2 \pm 10.1$ & $3.8 \pm 0.5$ & 8 & $103.9 \pm 11.9$ & $4.5 \pm 0.7$ \\
\hline $\mathrm{HCO}_{3}$-free, $\mathrm{Cl}$-free solution $\ddagger$ & 9 & $14.0 \pm 3.9$ & $0.6 \pm 0.2$ & 8 & $10.0 \pm 1.0 \$$ & $0.4 \pm 0.1 \S$ \\
\hline Ringer solution & & & & & & \\
\hline$+10 \mathrm{mM}$ theophylline & 7 & $14.6 \pm 7.3$ & $0.7 \pm 0.3$ & 一 & - & - \\
\hline$+0.5 \mathrm{mM}$ sodium ricinoleate & - & - & - & 9 & $37.4 \pm 7.4$ & $1.8 \pm 0.3$ \\
\hline
\end{tabular}

* Mean \pm SEM. Results represent the increase in $I_{s c}$ and PD that was determined by comparing the peak $I_{s c}$ and PD observed in the 10-min after the addition of either sodium ricinoleate or theophylline compared to that present immediately before their addition. $n$ represents the number of tissues in each group.

I Solution contained $1.2 \mathrm{mM}$ chloride in the form of $\mathrm{SrCl}_{2}$ as described in the text.

$\S$ Previously reported (21).

A significant increase in cyclic AMP content was noted during incubations with $0.5 \mathrm{mM}$ sodium ricinoleate for as short a time as 2 min (Fig. 3). The maximal increase in cyclic AMP was observed during incubations of 10 and $20 \mathrm{~min}$. Table I presents the effect of several concentrations of sodium ricinoleate on cyclic AMP content, during a 10 min incubation period, and on $I_{s c}$. The lowest concentration that produced a significant increase in cyclic AMP content was $0.1 \mathrm{mM}$, which was also the lowest dose

TABLE III

Effect of $0.5 \mathrm{mM} \mathrm{Na}$ Ricinoleate on Unidirectional and Net Na and Cl Fluxes*

\begin{tabular}{|c|c|c|c|c|c|c|c|c|c|c|c|}
\hline & \multicolumn{4}{|c|}{$\mathrm{Na}$ fluxes } & \multicolumn{4}{|c|}{$\mathrm{Cl}$ fluxes } & \multirow[b]{2}{*}{ PD } & \multirow[b]{2}{*}{$I_{\text {sc }}$} & \multirow[b]{2}{*}{ G } \\
\hline & $n$ & $\mathrm{~J}_{\mathrm{ms}}$ & $J_{s m}$ & $J_{\text {net }}$ & $n$ & $\mathrm{~J}_{\mathrm{ms}}$ & $\mathrm{J}_{\mathrm{sm}}$ & $J_{\text {net }}$ & & & \\
\hline \multicolumn{12}{|c|}{ Control tissue } \\
\hline Period I & 10 & $\begin{array}{r}16.1 \\
\pm 1.1\end{array}$ & $\begin{array}{r}10.4 \\
\pm 0.8\end{array}$ & $\begin{array}{r}5.7 \\
\pm 0.6\end{array}$ & 8 & $\begin{array}{r}21.3 \\
\pm 1.5\end{array}$ & $\begin{array}{r}16.6 \\
\pm 1.3\end{array}$ & $\begin{array}{r}4.8 \\
\pm 1.7\end{array}$ & $\begin{array}{l}-5.2 \\
\pm 0.5\end{array}$ & $\begin{array}{r}2.9 \\
\pm 0.3\end{array}$ & $\begin{array}{r}16.3 \\
\pm 0.8\end{array}$ \\
\hline Period II & 10 & $\begin{array}{r}15.4 \\
\pm 0.7\end{array}$ & $\begin{array}{r}10.7 \\
\pm 0.8\end{array}$ & $\begin{array}{r}4.7 \\
\pm 0.8\end{array}$ & 8 & $\begin{array}{r}20.4 \\
\pm 1.0\end{array}$ & $\begin{array}{r}15.9 \\
\pm 1.2\end{array}$ & $\begin{array}{r}4.5 \\
\pm 0.9\end{array}$ & $\begin{array}{l}-4.7 \\
\pm 0.4\end{array}$ & $\begin{array}{r}2.7 \\
\pm 0.3\end{array}$ & $\begin{array}{r}17.0 \\
\pm 0.9\end{array}$ \\
\hline$P \downarrow$ & & NS & NS & NS & & NS & NS & NS & NS & NS & NS \\
\hline \multicolumn{12}{|c|}{ Experimental tissue } \\
\hline Period I & 11 & $\begin{array}{r}13.7 \\
\pm 0.8\end{array}$ & $\begin{array}{r}9.7 \\
\pm 0.4\end{array}$ & $\begin{array}{r}4.0 \\
\pm 0.8\end{array}$ & 9 & $\begin{array}{r}21.5 \\
\pm 1.1\end{array}$ & $\begin{array}{r}17.9 \\
\pm 1.0\end{array}$ & $\begin{array}{r}3.6 \\
\pm 1.6\end{array}$ & $\begin{array}{l}-4.8 \\
\pm 0.4\end{array}$ & $\begin{array}{r}2.9 \\
\pm 0.3\end{array}$ & $\begin{array}{r}17.8 \\
\pm 0.9\end{array}$ \\
\hline Period II & 11 & $\begin{array}{r}11.0 \\
\pm 0.8\end{array}$ & $\begin{array}{r}10.9 \\
\pm 0.7\end{array}$ & $\begin{array}{r}0.1 \\
\pm 0.7\end{array}$ & 9 & $\begin{array}{r}15.2 \\
\pm 0.8\end{array}$ & $\begin{array}{r}17.4 \\
\pm 0.8\end{array}$ & $\begin{array}{l}-2.2 \\
\pm 0.8\end{array}$ & $\begin{array}{l}-5.5 \\
\pm 0.4\end{array}$ & $\begin{array}{r}4.1 \\
\pm 0.3\end{array}$ & $\begin{array}{r}22.6 \\
\pm 0.9\end{array}$ \\
\hline$P \ddagger$ & & $<0.05$ & NS & $<0.02$ & & $<0.001$ & NS & $<0.01$ & NS & $<0.01$ & $<0.001$ \\
\hline
\end{tabular}

* Results are expressed as mean \pm SEM. Unidirectional and net $\mathrm{Na}$ fluxes and $\mathrm{I}_{\mathrm{sc}}$ are expressed as microequivalents per hour per square centimeter, PD as millivolt (mucosa negative) and conductance (G) as millimho per square centimeter. $n$ represents number of tissues in the $\mathrm{Na}$ studies and tissue pairs in the $\mathrm{Cl}$ experiments. Unidirectional $\mathrm{Na}$ fluxes were performed with ${ }^{22} \mathrm{Na}$ and ${ }^{24} \mathrm{Na}$ across the same tissue; unidirectional $\mathrm{Cl}$ fluxes were performed on tissue pairs from the same animal using ${ }^{36} \mathrm{Cl}$. Period $\mathrm{I}$ is the mean of two 20 -min periods. $0.5 \mathrm{mM} \mathrm{Na}$ ricinoleate was added to the mucosal bathing solution of the experimental group at the conclusion of period I. Period II represents a single 15-min period that started $7 \mathrm{~min}$ after the addition of $\mathrm{Na}$ ricinoleate. Positive values for $\mathrm{J}_{\text {net }}$ represent net absorption, negative ones net secretion. \$ Represents the differences between periods I and II in control and experimental tissue respectively. 


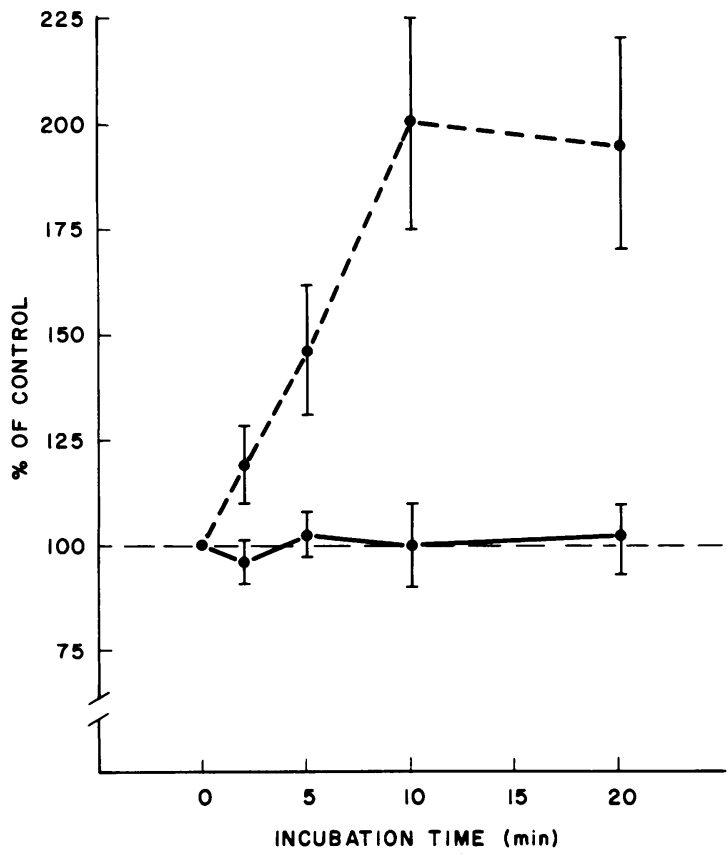

Figure 3 Time-course of the effect of $0.5 \mathrm{mM} \mathrm{Na}$ ricinoleate on mucosal cyclic AMP content. Colonic mucosa was incubated with (-- ) and without ( - ) the hydroxy fatty acid for $2,5,10$, and $20 \mathrm{~min}$. Results are expressed as the percentage of mucosal cyclic AMP content present at zero time. Significant increases were present at all time periods.

producing a significant increase in $I_{s c}$. Concentrations $>0.5 \mathrm{mM}$ resulted in less than maximal increases in cyclic AMP content and $I_{\text {sc }}$.

\section{DISCUSSION}

This study performed in vitro in the absence of chemical, electrical, osmotic, and hydrostatic pressure gradients demonstrate net chloride secretion and provide compelling evidence that ricinoleic acid stimulates active anion secretion. The results presented in Table III are very similar to the effect of theophylline, dibutyryl cyclic AMP, and vasoactive intestinal peptide on ion transport across rat colonic mucosa $(9,19,21)$. All four compounds increase $I_{s c}$, decrease $J_{\text {net }}^{\mathrm{Na}}$ to zero, and reverse net $\mathrm{Cl}$ absorption to net secretion. Their effect on unidirectional fluxes are also identical: a decrease $J_{\mathrm{ms}}$ without significantly altering $\mathrm{J}_{\mathrm{sm}}$. Sodium ricinoleate increases conductance, which is not observed with these other agents that increase mucosal cyclic AMP. It is of additional importance that parallel changes on $\mathrm{Na} \mathrm{Cl}$ transport are produced by cholera enterotoxin, theophylline, vasoactive intestinal peptide, and dibutyryl cyclic AMP in the ileum $(6,8)$. Because changes in mucosal permeability will not alter net ion movement in vitro across shortcircuited epithelium, these studies do not exclude a possible contributory role of altered permeability in the production of fluid secretion in in vivo situations.

There is considerable evidence that indicates that the increases in $\mathrm{I}_{\mathrm{sc}}$ and cyclic AMP produced by $\mathrm{Na}$ ricinoleate are causally related. First, Table I demonstrates that the threshold and maximal concentration of ricinoleic acid required to increase both $\mathrm{I}_{\mathrm{sc}}$ and mucosal cyclic AMP are identical. Second, increments in $I_{s c}$ and mucosal cyclic AMP are observed as soon as 2 min after the addition of the hydroxy fatty acid (Figs. 2 and 3). Third, the presence of theophylline inhibits the increase of $I_{s c}$ and PD usually produced by ricinoleic acid and conversely, theophylline induced increases in $I_{s c}$ and $P D$ are inhibited by the presence of ricinoleic acid (Table II). These phenomena have previously been observed when theophylline is added either to choleragen-treated ileal mucosa $(6,25,26)$ or to bile acid-exposed colonic epithelia (19) and have been attributed to increased mucosal cyclic AMP levels. Fourth, the pattern of changes of ion transport observed in the presence of ricinoleic acid (Table III) is almost identical to that observed in ileal mucosa after the addition of choleragen (6) or theophylline $(6,26)$, and in colonic mucosa after the addition of theophylline or dibutyryl cyclic AMP $(19,21)$.

There have been conflicting data on the effect of hydroxy fatty acids on cyclic nucleotides in the intestine. We presented preliminary studies indicating that ricinoleic acid increased mucosal cyclic AMP in studies similar to those in this report (27). Coyne et al. (28) have reported that hydroxy stearic acid increased adenylate cyclase activity in the rabbit colon but did not inhibit phosphodiesterase activity. These investigators also demonstrated that propranolol prevented the increase in adenylate cyclase activity produced by hydroxy stearic acid (28). These studies support the contention that cyclic AMP is important in the production of hydroxy fatty acid-induced fluid secretion. In contrast, Gaginella et al. (29) failed to observe a stimulation of adenylate cyclase in isolated epithelial cells of the hamster small intestine at all ricinoleic acid concentrations. These investigators reported that ricinoleic acid increased adenylate cyclase only at a concentration of $10 \mu \mathrm{m}$ and that higher concentrations of ricinoleic acid inhibited adenylate cyclase activity. It is possible that hydroxy fatty acids stimulate or inhibit adenylate cyclase activity in different pools in vitro but that the effect of cyclic AMP on fluid movement is only influenced by one of these pools.

Fatty acids have been observed to affect cyclic nucleotides in nonintestinal tissue. For example, several fatty acids including ricinoleic acid and oleic acid stimulate guanylate cyclase of fibroblasts (30). Similarly, arachidonic acid significantly increases 
human platelet guanylate cyclase (31). Finally, Orly and Schramm (32) observed that certain long-chain fatty acids, including oleic acid, increase isoproterenol stimulation of adenylate cyclase of turkey erythrocytes.

In conclusion, these studies demonstrate that sodium ricinoleate affects ion transport and that results are most consistent with a stimulation of active ion secretion. We have previously presented evidence that a coupled $\mathrm{NaCl}$ influx process is present in colonic mucosa of the rat (33), and the parallel decreases in $J_{\mathrm{ms}}^{\mathrm{Na}}$ and $\mathrm{J}_{\mathrm{ms}}^{\mathrm{Cl}}$ are consistent with inhibition of coupled $\mathrm{NaCl}$ influx. In the rabbit ileum and gallbladder coupled $\mathrm{NaCl}$ influx processes have been established and can be inhibited by cyclic AMP (3436). These present findings and those in both the ileum and gallbladder are very similar. Thus, we believe that the increases in $I_{s c}$ associated with a decrease in $\mathrm{J}_{\text {net }}^{\mathrm{Na}}$ and net $\mathrm{Cl}$ secretion can bèst be explained by stimulation of anion secretion together with inhibition of coupled $\mathrm{NaCl}$ influx. The failure to observe significant increases in $\mathrm{I}_{\mathrm{sc}}$ and $\mathrm{PD}$ in the $\mathrm{HCO}_{3}$-free, $\mathrm{Cl}$-free solution is consistent with this concept. We propose, therefore, that hydroxy fatty acids induce fluid and electrolyte secretion secondary to their stimulation of an active anion secretory process. This active anion secretory process is most likely mediated by cyclic AMP. It is apparent that hydroxy fatty acids also increase mucosal permeability, but to what extent this increase in mucosal permeability contributes to fluid accumulation is unknown.

\section{ACKNOWLEDGMENTS}

The authors wish to thank Ms. Giselle Chapo and Mr. Jeffrey DeLuca for expert technical assistance.

These studies were supported in part by a U. S. Public Health Service Research grant (AM 14669) from the National Institute of Arthritis, Metabolism, and Digestive Diseases and a grant from the John A. Hartford Foundation Inc.

\section{REFERENCES}

1. Bright-Asare, P., and H. J. Binder. 1973. Stimulation of colonic secretion of water and electrolytes by hydroxy fatty acids. Gastroenterology. 64: 81-88.

2. Ammon, H. V., and S. F. Phillips. 1973. Inhibition of colonic water and electrolyte absorption by fatty acids in man. Gastroenterology. 65: 744-749.

3. Ammon, H. V., P. H. Thomas, and S. F. Phillips. 1974 Effects of oleic and ricinoleic acid on net jejunal water and electrolyte movement. J. Clin. Invest. 53: 374-379.

4. Cline, W. S., V. Lorenzsonn, L. Benz, P. Bass, and W. A. Olsen. 1976. The effects of sodium ricinoleate on small intestinal function and structure. J. Clin. Invest. 58: $380-390$.

5. Gaginella, T. S., V. S. Chadwick, J. C. Debongnie, J. C. Lewis, and S. F. Phillips. 1977. Perfusion of rabbit colon with ricinoleic acid: dose-related mucosal injury, fluid secretion, and increased permeability. Gastroenterology. 73: 95-101.
6. Field, M., D. Fromm, Q. Al-Awqati, and W. B. Greenough, III. 1972. Effect of cholera enterotoxin on ion transport across isolated ileal mucosa. J. Clin. Invest. 51: 796-804.

7. Donowitz, M., and H. J. Binder. 1976. Effect of enterotoxins of vibrio cholerae, Escherichia coli, and Shigella dysenteriae type I on fluid and electrolyte transport in the colon. J. Infect. Dis. 134: 135-143.

8. Schwartz, C. J., D. V. Kimberg, H. E. Sheerin, M. Field, and S. I. Said. 1974. Vasoactive intestinal peptide stimulation of adenylate cyclase and active electrolyte secretion in intestinal mucosa. J. Clin. Invest. 54: 536-544.

9. Racusen, L. C., and H. J. Binder. 1977. Alteration of large intestinal electrolyte transport by vasoactive intestinal polypeptide in the rat. Gastroenterology. 73: $790-796$.

10. Al-Awqati, Q., and W. B. Greenough, III. 1972. Prostaglandins inhibit intestinal sodium transport. Nat. New Biol. 238: 26-28.

11. Yau, W. M., and G. M. Makhlouf. 1974. Different effects of hormonal peptides and cyclic adenosine $3^{\prime}, 5^{\prime}$ monophosphate on colonic transport in vitro. Gastroenterology. 67: 662-667.

12. Stewart, J. J., T. S. Gaginella, W. A. Olsen, and P. Bass. 1975. Inhibitory actions of laxatives on motility and water and electrolyte transport in gastrointestinal tract. J. Pharmacol. Exp. Ther. 192: 458-467.

13. Gullikson, G. W., W. S. Cline, V. Lorenzsonn, L. Benz, W. A. Olsen, and P. Bass. 1977. Effects of anionic surfactants on hamster small intestinal membrane structure and function: relationship to surface activity. Gastroenterology. 73: 501-511.

14. Dobbins, J. W., and H. J. Binder. 1976. Effect of bile salts and fatty acids on the colonic absorption of oxalate. Gastroenterology. 70: 1096-1100.

15. Stewart, J. J., T. S. Gaginella, and P. Bass. 1975. Actions of ricinoleic acid and structurally related fatty acids on the gastrointestinal tract. I. Effects on the smooth muscle contractility in vitro. J. Pharmacol. Exp. Ther. 195: $347-354$

16. Christensen, J., and B. W. Freeman. 1972. Circular muscle electromyogram in the cat colon: local effect of sodium ricinoleate. Gastroenterology. 63: 1011-1015.

17. Mathias, J. R., J. L. Martin, T. W. Burns, G. M. Carlson, and R. P. Shields. 1978. Ricinoleic acid effect on the electrical activity of the small intestine in rabbits. $J$. Clin. Invest. 61: 640-644.

18. Gaginella, T. S., J. C. Lewis, and S. F. Phillips. 1976. Ricinoleic acid effects on rabbit intestine. An ultrastructural study. Mayo Clin. Proc. 51: 569-573.

19. Binder, H. J., and C. L. Rawlins. 1973. Effect of conjugated dihydroxy bile salts on electrolyte transport in rat colon. J. Clin. Invest. 52: 1460-1466.

20. Binder, H. J., and C. L. Rawlins. 1973. Electrolyte transport across isolated large intestinal mucosa. Am.J. Physiol. 225: 1232-1239.

21. Binder, H. J., C. Filburn, and B. T. Volpe. 1975. Bile salt alteration of colonic electrolyte transport: role of cyclic adenosine monophosphate. Gastroenterology. 68: 503-508.

22. Brown, B. L., J. D. M. Albano, R. P. Ekins, and A. M. Sgherzi. 1971. A simple and sensitive saturation assay method for the measurement of adenosine $3^{\prime}: 5^{\prime}$-monophosphate. Biochem. J. 121: 561-562.

23. Lowry, O. H., N. J. Rosebrough, A. L. Farr, and R. J. Randall. 1951. Protein measurement with the Folin phenol reagent. J. Biol. Chem. 193: 265-275. 
24. Snedecor, G. W., and W. G. Cochran. 1967. Statistical Methods. 6th edition. The Iowa State University Press, Ames, Iowa. 549.

25. Powell, D. W., H. J. Binder, and P. F. Curran. 1973. Active electrolyte secretion stimulated by cholergan in rabbit ileum in vitro. Am. J. Physiol. 225: 781-787.

26. Field, M. 1971. Ion transport in rabbit ileal mucosa. II. Effects of cyclic 3',5' AMP. Am. J. Physiol. 221: 992-997.

27. Binder, H. J. 1974. Cyclic adenosine monophosphate controls bile salt and hydroxy fatty acid-induced colonic electrolyte secretion. J. Clin. Invest. 53: 7 a-8 a. (Abstr.)

28. Coyne, M. J., G. G. Bonorris, A. Chung, D. Conley, and L. J. Schoenfield. 1977. Propranolol inhibits bile acid and fatty acid stimulation of cyclic AMP in human colon. Gastroenterology. 73: 971-974.

29. Gaginella, T. S., S. F. Phillips, R. R. Dozois, and V. L. W. Go. 1978. Stimulation of adenylate cyclase in homogenates of isolated intestinal epithelial cells from hamsters. Effects of gastrointestinal hormones, prostaglandins, and deoxycholic and ricinoleic acids. Gastroenterology. 74: $11-15$.

30. Wallach, D., and I. Pastan. 1976. Stimulation of guanylate cyclase of fibroblasts by free fatty acids. J. Biol. Chem. 251: 5802-5809.

31. Glass, D. B., W. Frey II, D. W. Carr, and N. D. Nelson. 1977. Stimulation of human platelet guanylate cyclase by fatty acids. J. Biol. Chem. 252: 1279-1285.

32. Orly, J., and M. Schramm. 1975. Fatty acids as modulators of membrane functions: catecholamine-activated adenylate cyclase of the turkey erythrocyte. Proc. Natl. Acad. Sci. U. S. A. 72: 3433-3437.

33. Binder, H. J. 1978. Na and $\mathrm{Cl}$ transport across colonic mucosa in the rat. In Membrane Transport Processes. J. F. Hoffman, editor. Raven Press, New York. 1: 309-330.

34. Nellans, H. N., R. A. Frizzell, and S. G. Schultz, 1973. Coupled sodium chloride influx across the brush border of rabbit ileum. Am. J. Physiol. 225: 467-474.

35. Nellans, H. N., R. A. Frizzell, and S. G. Schultz, 1975. Effect of acetazolamide on sodium and chloride transport by in vitro rabbit ileum. Am. J. Physiol. 228: 1808-1814.

36. Frizzell, R. A., M. C. Dugas, and S. G. Schultz, 1975. Sodium chloride transport by rabbit gallbladder. Direct evidence for a coupled $\mathrm{NaCl}$ influx process. J. Gen. Physiol. 65: 769-795. 